\title{
Germany seeks to re-balance funding for research centres
}

Munich. Tensions over the reunification of Germany have fanned disagreements between the country's 16 Länder about how much each should pay towards research institutes in their region and what proportion of the costs of each institute should be shared jointly.

The balance of expenditure has been distorted by the effects of reunification, and the situation is being reassessed in the light of the fact that a temporary programme supporting the integration of east German research into the national research effort expires next year. The issue is important because a host Land that pays a significant proportion of an institute's budget can exert a corresponding influence over its research programmes.

There are three types of non-university basic research establishments in Germany, each funded in different proportions, federally and locally. The Bund-Land Kommission for Education Planning and Research Funding (BLK), the body that brokers political and financial agreements between federal and Länder governments, has been asked by the prime ministers of the Länder to propose new formulae for dividing funding responsibility between the two sides.

The budgets of the 16 large national research centres are divided 90:10 between federal government and the host Land. This formula is not under scrutiny, as it benefits each Länder to the same extent, and there is therefore no political reason why the centres should not be relatively evenly distributed.

The funding of the 68 Max Planck institutes is more problematic. Each institute receives half its money from the federal government, and half from the Länder. The latter share is further subdivided, with the host Land paying a quarter and the rest coming from a central fund, controlled by the Max Planck Society (MPG), to which all Länder contribute.

This formula enables the MPG to decide where its institutes should be placed, and what type of research each should do, on scientific grounds alone. But the result is that Länder with relatively few Max Planck institutes find themselves providing substantial support for institutes that have been established in other Länder.

Rheinland-Pfalz, for example, which has only two institutes, has taken the lead in arguing that the host Land should pay much more, perhaps even all of the Länder share. In contrast, Bavaria, with several institutes, strongly supports the status quo.

Even more problematic are the other publicly-funded basic research institutes, known collectively as Blue List as they were originally listed on blue paper. These also receive half their funding from the federal government, but have no general formula for distributing the Länder share.

In principle, the host Land pays the full 50 per cent. In most cases in western Germany, part of this is reimbursed from a communal pool intended to help even out local expenditure on research between Länder. But so far the many Blue List institutes in the new Länder - created primarily as a way of continuing to support good science in the Academy of Sciences in the former East Germany - have not benefited from the same reimbursement mechanism.

Yet because there are so many of them - after reunification the number of Blue List institutes jumped from 48 to 82 most of the old Länder want to make sure that the new eastern Länder do not receive such reimbursement in future either.

Because of this sudden growth, a new umbrella group for all Blue List institutes, whose total budget is now similar to that of the MPG, was created in 1992. The socalled AG-BL would like to be given similar control over the finances of its institutes as the MPG, but at present this remains a distant dream.

The new Länder themselves are keenly aware of the disadvantage of being excluded from the reimbursement mechanism of the west, particularly as their research is heavily locked into the Blue List system. (Only three relatively small national research centres were established in the east, while the MPG prefers not to take over existing research teams, and is only slowly founding institutes.)

But only three of the smallest western Länder - Berlin, Bremen and SchleswigHolstein - feel that the heavy costs of Blue List institutes in the new Länder should even be shared by the reimbursement method. Richer and more powerful old Länder, such as Bavaria, Baden-Württemberg and Nordrhein-Westfalen, oppose the idea, as they would have to bear most of the subsidy.

Michael Lankeit, a spokesman for the AG-BL, says the issue of who should pay what must be resolved soon to enable the organization to start taking over new institutes, and perhaps closing others. (Germany's science council, the Wissenschaftsrat, last year recommended a further eight institutes be added to the Blue List, but so far no action has been taken).

But he is pessimistic about an agreement being reached by September, as requested by the Länder prime ministers. "The sides are too far apart," he says. Alison Abbott

\section{US agencies bury hatchet over aid to Russian science}

Washington. After nearly three years of delay, and heated wrangling between federal agencies, the United States last week agreed to provide $\$ 5$ million to help set up a fund for collaborative research between US scientists and researchers in the former Soviet Union (FSU).

The grant was announced by President Bill Clinton during a Moscow summit meeting with the Russian President, Boris Yeltsin. Money from a defense conversion fund taken out of the budget of the Department of Defense will be matched by the philanthropist George Soros.

The two sums will provide a total of $\$ 10$ million to create a Civilian Research and Development Foundation. The Russian government has promised another $\$ 10$ million to the fund, and other former Soviet states are expected to provide additional resources.

Congress authorized the creation of the foundation in 1992, as part of its effort to redirect military funding to civilian projects, at the insistence of George Brown (Democrat, California), the former chairman of the House of Representatives Science committee.

But the Defense Department stubbornly refused to release the funds to get it off the ground. Its lawyers argued that they were not legally entitled to release any money unless it was matched by another federal agency (see Nature 372, 717;1994). Soros, equally stubborn, had initially vowed not to give any more money to support Russian science unless it was matched by the US government, but his new move is said to have broken the log-jam by giving the money to a National Science Foundation (NSF) trust fund, allowing NSF to become the matching agency.

Now that both sides have relented, the NSF will establish the foundation as a private, nonprofit organization with an independent board of directors. Tom Owens of the NSF's international programmes division says he expects the board to be in place by the end of next month. The first task of the board will be to work with Russian and other FSU science agencies on deciding which areas of research should be funded.

Owens says that "the overwhelming proportion" of funds will be spent in the former Soviet Union. Although each project will have US collaborators, these would generally receive only travel costs and other "marginal" expenses. The foundation's funds will be split evenly between support for basic science projects and for technology projects with potential commercial applications. Tony Reichhardt 